
UNACCEPTABLE THESES

David Haws, Boise State University 


\title{
Women on the Margin of Engineering: Acceptable and Unacceptable Theses
}

\begin{abstract}
What demographics should an engineering faculty reflect, and how might it acceptably differ in appearance from its students, the broader community, or the narrower complex of professionals and research consumers it purports to serve? Of course, we are horribly partial to our own DNA, but we can also reason through to the needs of society and put aside our personal bias. Similarly, our professional and research colleagues (perhaps most akin to us) should also be willing to defer to our expertise, when we select appropriate faculty fellows. While the broader community may not understand our expertise (disciplinary or collegial), they seem primarily concerned that we not raise their mill levy, seduce their sons and daughters, or (successfully) man the barricades. So long as we look reasonably penurious, chaste, and bungling, the broader community will probably, within limits, be less concerned with how we might otherwise appear.
\end{abstract}

We will (hopefully) spend more time with our students than with either those who hire our students, or the general public and special interests that support our institutions. Consequently, the face we turn to our students is arguably more important. Faculty may need to defer to what their students (reasonably or not) consider conducive to their own learning experience. This may mean that faculty need to either expose or conceal erudition - may need to either fraternize or distance themselves from their students - and may need to look either sufficiently like or unlike their students to both teach and motivate.

Lawrence Summers, in his cavalier remarks to the National Bureau of Economic Research Conference in January of 2005, may have been more provocative than he had intended. Noting the under-representation of women on engineering faculties at "top-25" research universities, he proposed the intentionally grating thesis that the fault lies with women, rather than with the patterns of faculty search and selection. While he doesn't deny the contribution of systematic bias, he feels it more cogent to believe that women may generally lack an innate proclivity within the underrepresented disciplines (his "biology" thesis). Alternately, women may lack the desire and/or a gender role consistent with clocking 80-hour workweeks, behind an appropriately mementoed desk, over the requisite span of decades needed to produce the kind of academic track record naturally sought in new hires (what he calls the "high-powered job" thesis).

Since the institutions being considered are looking for faculty among the extreme outliers within the considered disciplines (Summers suggests something on the order of $3 \frac{1 / 2}{2}$ to 4 Standard Deviations), you wouldn't expect such individuals to be very representative of the population they so out-distance. In fact, the act of seeking faculty among such outliers might itself be considered a source of systemic bias. I suppose that both of Summers' theses might be put to better use in trying to account for the under-representation of women on more modest engineering faculties. To keep his theses more consistently focused on the intrinsic, putative weakness of women applicants, I prefer to consider them the objective (biological) and subjective (psychological) theses. 
In this paper, I would like to examine the phenomenon of under-representation in engineeringwhat our faculty ought to look like, why it might reasonably be obliged to look a certain way, and how any cosmetic faculty prescriptions (or proscriptions) might entail changes in the performance of both faculties and students. Given the goal of engineering education (to fill the profession with an adequate number of competent practitioners) the theses put forward by Summers ${ }^{i}$ seem somewhat misdirected.

\section{The Outlier Myth}

Of course, I'm sure that white, male engineers would never intentionally fabricate the smokescreen of credentials that only they-or primarily they-happened to possess. But if we really have to be so credentialed to teach engineering classes, how is it that adjuncts (let alone graduate students), not having emerged through the crucible of faculty tenure selection, are able to perform as well as they do? The cursory reference to teaching in our faculty advertisements would seem to indicate that such ability is a hygiene factor-something given little value until it is obviously missing. Alternately, a faculty search committee may feel that their students are bright enough to require only the most rudimentary skill on the part of an instructor.

If, on the other hand, outliers are selected for their grantsmanship rather than teaching, why don't we just leave them all on soft money and let them write their own salaries? Or for that matter, why don't they just go to a research park and negotiate a reduced rate of institutional overhead? Salaries for research faculty would probably increase and we could certainly introduce them to all the graduate students they might need.

Most administrations (not just those narrowly academic) justify their existence by the rate of growth experienced during their watch. The calculus of faculty performance requires numbers for both teaching and research, and administrator want faculty (ceteris paribus) who generate their own, and a portion of the administrator's salary. But state funding for teaching is relatively fixed, and the rate of growth in grant funding is at least potentially much greater. Such green pastures are more alluring than the prospect of wringing more student credit hours from existing faculty. In addition, student-perception-of-teaching scores have little inter-institutional comparability, while research dollars don't typically morph as one moves between Boston and Boise. Maybe administrators are being smart (as well as self-motivated) when they emphasize research over teaching, but future faculty performance in both teaching and research is fundamentally unknown.

Statistics is all about the past - search committees take a comparative look at past performance, making assumptions and creating expectations. But as Feynman was so keen to point out, their expectations create no moral obligation on the part of selected faculty. Given the Problem of Induction, ignoring reasonable constraints on how a faculty should look (something that we can control) in deference to how a faculty might perform (something we can only hope to influence, rather than control) seems a rather poorly chosen criterion.

Summers' engineering faculty may indeed operate standard deviations above me, but what difference does that make? If the point is to appear very smart to Summers, then it may be 
enormously important. But outlier intelligence doesn't bear on any of the substantive things we do as a faculty: teach our students, reflect on our disciplines, advance our disciplines, branch into corollary disciplines, and interact with our colleagues.

\section{Expert Modeling}

Engineering faculties need to meet modest, minimal criteria to appear as experts to their students. Here, we are clearly focused on the reasonable expectations of what our faculty should look like - if only considering the paper trail behind their resume - rather than on how that faculty should perform. However, the appearance of expertise on paper, while generally necessary, is often insufficient in itself. Just as students need to be humble to be teachable (they need to recognize that there is something they don't know), teachers need to convince their students that they, as teachers, are the ones to whom students should look to define the things that students don't know, to transfer the desired knowledge that students lack, and to warrant whether that transfer has been successfully achieved.

Engineering students are obviously in the best position to decide who they are willing to accept as expert models. If faculty duties were confined to teaching, potential faculty should probably be approved by the department, but selected by existing students (much as the old privatdozent). But because students are typically oblivious to other faculty contributions, student input on faculty hiring needs to be somewhat more limited.

Engineering faculties, as the guardians of their students' education, are perhaps in the next best position to know who those students will accept. They are also in the best position to determine whether proposed faculty will meet the minimal expectations of their colleagues. Clearly, most engineering faculties require their tenured members to have a Ph.D. in the discipline they teach. This is probably more than undergraduates would generally require, but university colleagues tend to guard their own status, and departments ignore the "hygiene factors" in faculty selection at their own peril. In additions, some faculties require sufficient communication skills so that language does not form an additional barrier between important knowledge, and the students who may already be overly confused about what that knowledge is.

Engineering Ph.D.s and English language skills do not always go together, but the pool of general applicants does appear to be a sufficiently deep. If it is believed that women and minorities are underrepresented in such a pool, the problem might be addressed in the long term through proactive training and in the short term by relaxing the standards for candidacy. Clearly, any relaxations in "expert" standards should be made in deference to the perception of students, rather than faculty. In other words, women and minorities who meet the students' reasonable criteria for expertise should not be rejected because they fail to meet the similar criteria of existing faculty.

\section{Peer Modeling}

Jovian as we may appear, we are not the Olympians to whom our students pray; at best, we are the penates. When a student comes to ask me a question, she or he already has a fair idea of the answer; the act of scholastic supplication combines a need for clarification with the need for 
recognition, neither of which I begrudge. When a student is really lost or lacks confidence, expert modeling is of little help. Floundering students need someone with an understanding closer to their own-someone whose success at mastering the content they feel competent to emulate.

Our best, realistic hope is that students will become competent professionals. Few, if any, will become the outliers whose general understanding far out-distances our own. While these individuals of rare genius are extremely important, to the professions and to society, they are far too rare to warrant more than a passing acknowledgment in our teaching plans. What's more, you don't need to be a genius to help a genius understand something-more typically, you simply need to get out of the way. Expert models are not required by geniuses, and geniuses don't require peer models. But to the extent that faculty can function as peer models, their so functioning is independent of, and at least occasionally compatible with their functioning as expert models.

Outlier faculty, although they may garner more respect as expert models and faculty colleagues, are often too credentialed to meet the needs of undergraduates for peer models. Many undergraduates are looking for a quick degree and the main chance, and will only come to understand the true value of their education in later life. The value of education is found more in the breadth of one's comprehension, rather than the letters after one's name-but many undergraduates assume that the two are synonymous, and aren't particularly interested in the former. In addition, by the sheer depth of their expertise, many faculty members are often too narrowly focused (academically) to serve as peer models for their more broadly disciplined students.

As peers, engineering faculty members are most effective modeling the profession, motivating their students by instilling a confidence in where the student might be in four or five years through the sufficient application of personal effort. To function appropriately as peer models, faculties need to maintain professional interests (this is why a PE is so important in some engineering disciplines). It is in the motivation of peer modeling that the physical appearance of faculty become so important.

If there are no women or minorities on an engineering faculty, students unrepresented by those missing faculty will have to look elsewhere for "professional" peer models. Unless they are lucky enough to know someone (or know someone caring, like a parent, who knows and can introduce them to someone) they are unlikely to happen upon an appropriate model. Only those among the underrepresented who are themselves outliers will find sufficient motivation without being able to relate to someone within the profession who looks like them.

\section{Rawls' Second Principle of Justice}

Rawls' Second Principle of Justice bears significantly on the obligation to promote diversity within our engineering faculties. A professorship is a primary good (an office), which enables an inequality of benefits. As such, under the original formulation of the Second Principle, such an inequality of benefits could only be justified on merit, contingent that the least-well-off were also benefited by the services thus provided. Assuming that white, male faculty did put in 80 -hour 
weeks (the subjective/psychological thesis) and actually were better engineering professors (the objective/biology thesis), the marginalization of women and minorities might be justified on the basis of benefit to the least advantaged. You would still have to establish that "better" professors teaching "better" (i.e., white male) students somehow benefits the least advantaged (dubious, given the qualitative impact of engineering projects on disadvantaged neighborhoods), but more to the point, you would have to justify ignoring the formulation with which Rawls ended his career, holding that such offices as deliver an inequality of benefits have to be open to allparticularly with reference to the primary good he calls the social basis of self respect.

Thurgood Marshall's demonstration of the preference for white dolls among segregated, AfricanAmerican children was an undeniable indictment against segregation; whatever else that system might have done, it denied many the social basis of self respect. Homo sapiens exist in their minds, and no purely material gains can compensate for the pain and suffering endured through the social infliction of poor self-esteem. Our professions and our faculties need to enable the social basis of self-respect in all Americans - even if the quality of our teaching and engineering were to suffer. That such loss of quality only seems inevitable in the minds of those who hold to the objective and subjective theses, detracts little from the incentive to make our faculties more inclusive.

\section{Conclusion}

There may be good reasons for research institutions to pay little more than lip-service to teaching goals. Students at research schools may have less need for expert models and didactic interaction. Additionally, the quality of individual teaching effort seems esoteric, and represented by ordinal numbers (e.g., student-perception-of-teaching), at best. In comparison, the assessment of research (grants and publications) seems much more straight-forward, perhaps even becoming amenable to representation by rational numbers. However, Summers' explicit assumption-that "top-25" institutions take their engineering faculty from the extreme outliers among research performers - seems to have embraced the fallacy that past performance is a primary result of the ontologically discontinuous applicant. It is far more plausible that scholastic achievement is the result of many symbiotic factors, both internal and external to the scholar, which may not "travel" with the selected faculty to the new institution.

Summers' implicit assumptions regarding the future performance of selected faculty seem even more fallacious:

- that grants and publications comprise a faculty's most significant activities;

- that there is a positive correlation between outliers with regards to past performance and similar outliers with regards to future performance; and

- that there is any good reason to infer a causal connection between past performance and future performance (the Problem of Induction).

Even if our search committee assessment of faculty potential, based on past performance (really just are best guess) were accurate, there would still be social goals, better served with a greater degree of certainty by emphasizing something other than the teaching/research track record of applicants. The past performance of prospective faculty is less important than the future 
performance of our graduates. Our most informed guess is that the performance of alumni would be expected to improve if our faculties were to become more demographically inclusive.

The question is not whether men are more generally inclined towards careers in engineering than women. The question is how, in accordance with Rawls' Second Principle of Justice, we insure that careers in engineering - including careers as engineering professors - are open to all. We can't deny the fundamental human need to believe that society cares enough about us to afford a reasonable basis for our caring about our selves.

\footnotetext{
${ }^{\mathrm{i}}$ Summers, Lawrence H. Remarks at NBER Conference on Diversifying the Science and Engineering Workforce, January 14, 2005. http://www.president.harvard.edu/speeches/2005/ nber.html.
} 